\title{
Small-scale disturbance in a stable canopy dominated community: implications for macroalgal recruitment and growth
}

\author{
Gunnar Cervin $^{1,3, *}$, Per Åberg ${ }^{1}$, Stuart R. Jenkins ${ }^{2}$ \\ ${ }^{1}$ Göteborg University, Department of Marine Ecology, Marine Botany, Box 461, 40530 Göteborg, Sweden \\ ${ }^{2}$ Marine Biological Association, Citadel Hill, Plymouth PL1 2PB, UK \\ ${ }^{3}$ Present address: Göteborg University, Department of Marine Ecology, Tjärnö Marine Biological Laboratory, \\ 45296 Strömstad, Sweden
}

\begin{abstract}
The long-living species Ascophyllum nodosum dominates the mid-shore of sheltered rocky sites in NW Europe, forming near-monospecific stands. We aimed to determine the effects of small-scale disturbance on such shores, through manipulative experiments over a long period (almost $7 \mathrm{yr}$ ). We tested the general hypothesis that small-scale disturbance allows co-existence of Fucus canopy ( $F$. vesiculosus, F. serratus) and promotes recruitment of Ascophyllum itself. Two factorial experiments were established to determine the interactive effects of the Ascophyllum canopy with: (1) the red algal turf which covers approximately $90 \%$ of the substratum at the experimental sites, and (2) the dominant grazer, the limpet Patella vulgata, which maintains small patches of open substratum free from turf. Disturbance to plots $25 \times 25 \mathrm{~cm}$ resulted in significant changes to the understorey community. Removal of limpets led to high levels of Ascophyllum and Fucus recruitment, irrespective of the presence of the canopy. In the presence of limpets recruitment of fucoids was negligible. In contrast, removal of turf alone led to high Fucus spp. but not Ascophyllum recruitment. Loss of the canopy and a consequent degradation of the turf was required to promote Ascophyllum recruitment. Despite high recruitment in some treatments beneath an intact canopy, low growth rates in shade prevented development of mature plants. Loss of the overlying Ascophyllum canopy was followed by development of a mixed $F$. serratus/F. vesiculosus canopy that was still present nearly $7 \mathrm{yr}$ after manipulation. Ascophyllum recruits, while showing enhanced growth in the absence of the canopy, were too slow-growing to form a canopy.
\end{abstract}

KEY WORDS: Ascophyllum nodosum · Fucus spp. C Canopy disturbance $\cdot$ Recruitment $\cdot$ Interspecific competition · Rocky shores

\section{INTRODUCTION}

Throughout NW Europe canopy forming macroalgae dominate community assemblages in sheltered locations. Shores sheltered from wave action typically support dense uninterrupted stands of canopy macroalgae which appear to show a high level of stability through time (Lewis 1964, Jenkins et al. 2004). The midshore of such sites are dominated by the long-living species, Ascophyllum nodosum, which competes for space with
2 other fucoid algae, Fucus vesiculosus and F. serratus (David 1943, Hawkins \& Harkin, 1985, Jenkins et al. 1999a). Numerous manipulative experiments have demonstrated the important role of canopy algae in structuring communities. Canopy algae alter the physical environment at the substratum through lowering the light levels (e.g. Reed \& Foster 1984), amelioration of physical extremes (e.g. Hawkins 1983), reduction of water movement (e.g. McCook \& Chapman 1991), and by the physical abrasion of sweeping algal fronds (e.g. 
Velimirov \& Griffiths 1979). Loss of canopy algae typically results in recruitment of ephemeral algae which take advantage of the creation of unshaded space, followed by recruitment of longer lived species including the manipulated species itself (Lubchenco 1986, Chapman 1989, Benedetti-Cecchi \& Cinelli 1992).

Despite the obvious success of Ascophyllum, the sparsity of new recruits beneath the canopy has long attracted comment (Oltmanns 1889, David 1943, Knight \& Parke 1950, Printz 1956, Baardseth 1970, Sundene 1973, Lazo et al. 1994), especially given its high investment in reproduction. Estimates of gamete production suggest a potential egg rain of $2.5 \times 10^{9}$ eggs $\mathrm{m}^{-2}$ during a single reproductive season. Detailed observations by Åberg \& Pavia (1997), at a range of spatial scales on the Isle of Man and Sweden, suggest densities of new recruits may be higher than previously reported with a mean of 40 juveniles $\mathrm{m}^{-2}$ ( $<1 \mathrm{~cm}$ in length). However, such juveniles were extremely patchily distributed, with a large proportion $(>75 \%)$ of the replicated sampling areas $(0.25 \times$ $0.25 \mathrm{~m}$ ) containing no juveniles at all. Thus, it appears that while the recruitment level of Ascophyllum has the potential to be huge, this potential is only reached in small patches where very high densities may be reached. In contrast to Ascophyllum, adults of Fucus species, which occupy this mid-shore zone on more exposed shores, occur only rarely and in small patches. Surprisingly, considering the sparcity of adults, Fucus juveniles are relatively common, although only reach high densities on removal of the overlying Ascophyllum canopy (Keser et al. 1981, Keser \& Larson 1984, Jenkins et al. 1999a).

In recent years Petraitis and co-workers (e.g. Petraitis \& Latham 1999, Dudgeon \& Petraitis 2001) have experimentally investigated the role of large-scale disturbance on sheltered Ascophyllum dominated shores of the Gulf of Maine. Such shores are regularly impacted by ice scour and hence loss of Ascophyllum can occur on a large scale. This work has led to a lively debate on the presence of alternate stable states in sheltered intertidal communities with disturbance by ice scour implicated as the agent responsible for switching between Ascophyllum and mussel dominated communities. In contrast to the ice impacted shores of the Gulf of Maine, the majority of sheltered Ascophyllum dominated shores experience low levels of disturbance owing to the lack of significant wave action. For example in a 12 yr study of a sheltered shore in the Isle of Man, Jenkins et al. (2004) showed that the Ascophyllum canopy in control plots varied between 80 and $100 \%$. Patches of exposed substratum were rarely more than $0.25 \mathrm{~m}^{2}$ (S. R. Jenkins pers. obs.). Loss of Ascophyllum plants on such shores is likely to be limited to 1 or 2 plants in small areas or loss of fronds through grazing damage (Viejo \& Åberg 2003). We aimed to determine the long term (almost $7 \mathrm{yr}$ ) effects of small-scale disturbance in a stable canopy dominated community on the recruitment and growth of fucoid canopy algae (Fucus serratus, F. vesiculous and Ascophyllum nodosum).

Previous work in the Ascophyllum zone of sheltered shores has highlighted 3 factors: space pre-emption by turf forming algae, grazing by patellid limpets and shading/whiplash by the overlying dominant canopy, which may potentially limit the recruitment and growth of Ascophyllum nodosum and Fucus species (Jenkins et al. 1999a). In a review of extrinsic variables known to affect the recruitment of early post settlement stages of algae, Vadas et al. (1992) concluded that these 3 factors are the most generally important across a wide range of habitat and algal types. The understorey community of sheltered Ascophyllum dominated shores in the UK can be divided into 2 separate functional units: (1) a multispecies, sediment trapping red algal turf, interspersed with (2) patches of substratum, kept clear of erect algae by the grazing of Patella vulgata. These 'bare' patches consist of a mosaic of bare rock and encrusting algae. Disturbance in macroalgal dominated communities, whether from anthropogenic effects such as trampling (e.g. Schiel \& Taylor 1999) or physical effects such as wave action (e.g. Dayton \& Tegner 1984) is most likely to impact canopy cover. However Jenkins et al. (1999a, 2004) showed that canopy loss can also cause disturbance to the algal turf through exposure of turfing algae to high insolation and dessication stress, thus opening up bare patches of substratum. Additionally, the aggregated nature of limpets in this system, in small patches, bounded by algal turf, dictates that any localised increase in predation pressure, for example from avian predators (Coleman et al. 1999) or crabs (Thompson et al. 2000), will result in a reduction in local grazing pressure.

We tested the general hypothesis that small-scale disturbance to the dominant Ascophyllum nodosum canopy and to the understorey community of turf and patellid grazers allows co-existence of Fucus canopy (F. vesiculosus, F. serratus) within the Ascophyllum zone and promotes recruitment of Ascophyllum itself. Specifically, we tested the hypothesis that successful fucoid recruitment was reliant on provision of ungrazed substrata irrespective of the presence of an overlying canopy, but that development of mature canopy plants was reliant on canopy loss.

In 2 separate experiments we manipulated the presence of the overlying canopy in conjunction with 2 other components of this midshore zone: (1) the red algal turf which forms part of the understorey community; and (2) the dominant limpet grazer Patella vulgata. The effects of manipulation on the recruitment of 
both Ascophyllum and Fucus species (F. serratus and F. vesiculosus), and development of new canopy were determined.

\section{MATERIALS AND METHODS}

Study site and community patterns. The experiments were set up in August 1997 on the gently sloping, sheltered shores of Derbyhaven and Langness, on the south coast of the Isle of Man $\left(54^{\circ} 50^{\prime} \mathrm{N}\right.$, $\left.4^{\circ} 37^{\prime} \mathrm{W}\right)$. These shores are dominated by fucoid canopy algae over their vertical extent and support extensive beds of Ascophyllum, between 2.5 and $5 \mathrm{~m}$ above lowest astronomical tide. The problematic nature of working on understorey communities beneath large canopy algae, and the need for relatively high levels of replication of experimental units owing to high variability in Ascophyllum recruitment, prevented replication of the experiment with spatial scale as a separate factor. However, the experiment was distributed over a large spatial area, approximately $2 \mathrm{~km}$ of horizontal distance. Thus, the results can be considered general for sheltered shores in the south of the Isle of Man.

The sheltered shores used are described in detail in Jenkins et al. (1999a). The midshore was dominated by a $100 \%$ cover of Ascophyllum with occasional patches of Fucus serratus and rarely F. vesiculosus. Red algal turf was the dominant component of the understorey with a mean cover of approximately $90 \%$ at Langness. The turf consisted of a number of red algal species, predominantly Chondrus crispus, Gelidium pusillum, G. latifolium, Corallina officinalis, plus others such as Osmundea spp., Audouinella floridula and Lomentaria articulata. The thalli of these algae bound a layer of silt, which in the undisturbed community ensured that, where present, the turf formed a continuous cover over the rock surface. The remainder of the understorey was made up of patches of bare substratum grazed by Patella vulgata. The overall density of adult $P$. vulgata at mid tide level on the sheltered shores in the south of the Isle of Man was approximately $10 \mathrm{~m}^{-2}$ (Jenkins et al. 1999a). Owing to the restriction of limpets to small patches of bare substratum, the density, calculated as number per unit area of grazeable substrate was much higher, with a mean value of $57 \mathrm{~m}^{-2}$.

Experimental work. In 2 separate experiments a 2way factorial design was used to test: (1) the interactive effects of the Ascophyllum canopy and the red algal turf (turf experiment), and (2) the interactive effects of the Ascophyllum canopy and the limpet Patella vulgata (limpet experiment), on the recruitment of Ascophyllum, Fucus and other components of the understorey community. In the first experiment, manipulations were done in areas where the understorey was domi- nated by turf, whilst in the second experiment manipulations were done on open rock grazed by limpets. In both experiments the factors had 2 levels, presence and absence, resulting in 4 orthogonal treatments, which were replicated 6 times. The plots in both experiments were small, only $25 \times 25 \mathrm{~cm}$, and were marked in the corners with stainless steel screws drilled into the rock. All the plots in the 2 experiments were randomly placed and intermingled on the 2 shores over approximately $2 \mathrm{~km}$ of shoreline. They were placed in the middle of the Ascophyllum zone, with a minimum distance of $3 \mathrm{~m}$ between the plots.

The treatments were applied to create a disturbance at the scale of these $25 \times 25 \mathrm{~cm}$ plots, although the exact area of disturbance varied because of the differing sizes of the manipulated organisms. The disturbance common to both experiments, canopy removal, was applied in exactly the same manner. All Ascophyllum plants inside the plot were removed with a chisel as close to the substrate as possible. Plants outside the experimental area, which could overlie it, were cropped. This left a circular patch of $40 \mathrm{~cm}$ in diameter in which there was no physical abrasion by adult fronds during any state of the tide. Subsequent growth of these cropped plants was left unchecked such that by the final sampling date in 2004 many of the experimental plots were once again completely covered by a canopy of Ascophyllum. In the turf experiment the $25 \times$ $25 \mathrm{~cm}$ plots that required turf removal were brushed clear with a wire brush. In the limpet experiment, in order to avoid the use of fences to exclude limpets, small natural patches of bare rock bounded by dense turf were used. Observations have shown that limpets do not graze over turf and so their movements are naturally curtailed (Jenkins et al. 1999a). Small patches of bare rock within the algal turf were chosen which could accommodate an experimental plot of $25 \times$ $25 \mathrm{~cm}$. In plots, which required limpet removal, all limpets were removed from the patch. A low level of limpet recruitment occurred over the time course of the experiment. These juveniles were removed from limpet exclusion plots at each sampling date. Grazing pressure from the new recruits in limpet exclusion plots was insignificant compared to grazing in control plots.

Sampling. The experiment was sampled in March 1998, when Ascophyllum started to release their gametes, in November 1998 when the juveniles had grown for about 7 mo, 1 yr later in November 1999 following a second reproductive event, and in May 2004, almost $7 \mathrm{yr}$ after establishment of the experiment. The percentage cover of all macroalgae and the number of Ascophyllum and Fucus spp. juveniles were determined at each sampling date. Percentage cover was estimated in the whole $25 \times 25 \mathrm{~cm}$ plot by overlaying a quadrat 


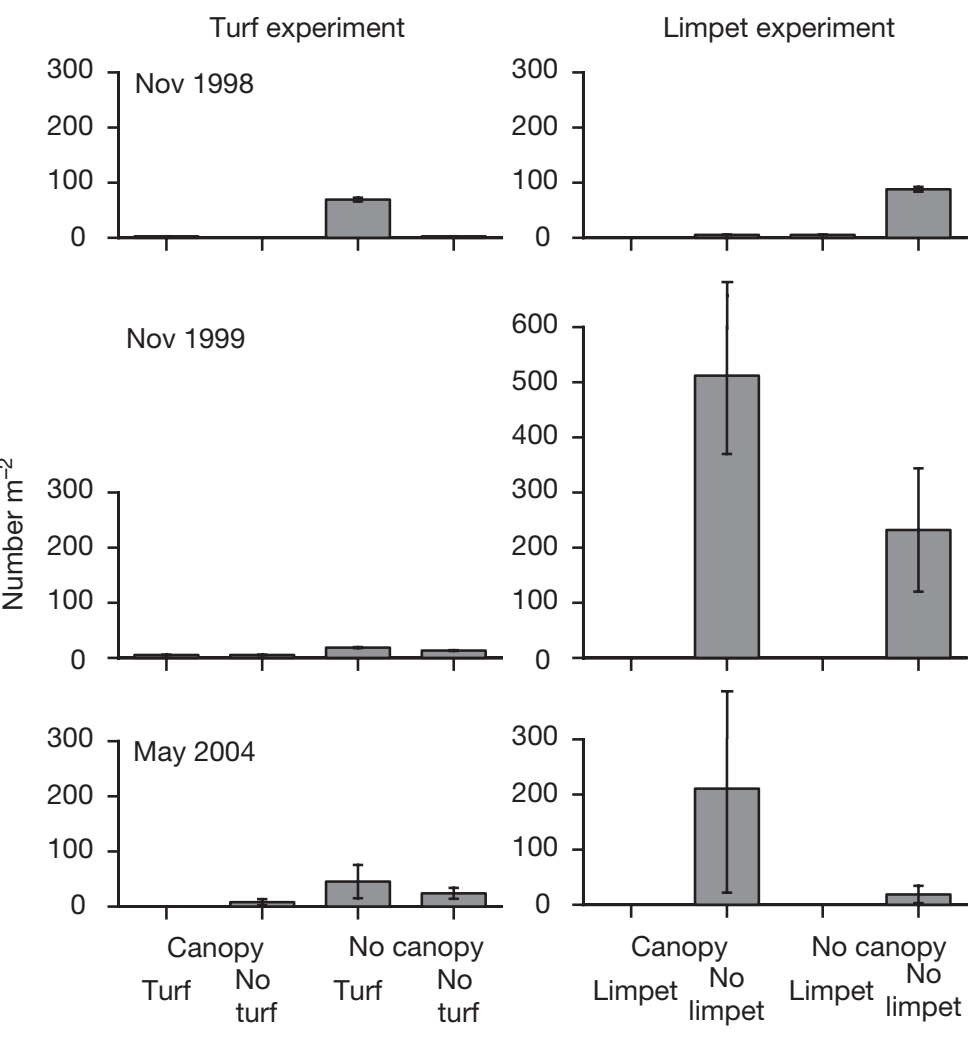

Fig. 1. Mean number of Ascophyllum recruits $\mathrm{m}^{-2}$ at 3 sampling dates in the turf and limpet experiments $( \pm \mathrm{SE})$

subdivided into 25 squares. In experimental plots with slow algal growth (typically beneath an intact canopy) the 2 Fucus spp. (F. serratus and F. vesiculosus) could not be distinguished at the first 3 sampling dates. Therefore these 2 species were only separated at the final sampling date in 2004. In November 1998, 1999, and
May 2004 the length of all Ascophyllum juveniles in the experimental plots were measured. A subset of Fucus juveniles were measured owing to their extremely high densities in many plots.

Statistical treatment of data. Analysis of the experiments was performed using 1- or 2-way ANOVAs in SuperANOVA. All factors manipulated were considered fixed. Heterogeneity of variances was tested for using Cochran's test, and where appropriate, $\log$, square root or arcsin transformations were applied (Winer et al. 1991).

\section{RESULTS}

\section{Ascophyllum recruitment}

Ascophyllum juveniles were not observed at the first sampling point in March 1998 in either the limpet or turf experiments but were visible in November 1998 when the maximum size was $20 \mathrm{~mm}$. In the turf experiment, recruitment only occurred to any degree where the canopy was removed (Fig. 1). In 1998 Ascophyllum juveniles were abundant in only one treatment, where the canopy was removed, but turf left intact (Fig. 1). Mean densities were over 60 juveniles $\mathrm{m}^{-2}$, mainly growing on the fronds of the turfforming algae. ANOVA showed an interaction between turf and canopy (Table 1), although variances were significantly heterogenous. Low recruitment where both the canopy and turf were removed may have been caused by the colonisation of these plots by

Table 1. ANOVA of Ascophyllum recruit number in the turf and limpet experiments

\begin{tabular}{|c|c|c|c|c|c|c|c|c|c|c|}
\hline \multirow[t]{2}{*}{ Source } & \multirow[t]{2}{*}{ df } & \multicolumn{3}{|c|}{ November 1998} & \multicolumn{3}{|c|}{ November 1999} & \multicolumn{3}{|c|}{ May 2004} \\
\hline & & MS & $F$ & $\mathrm{p}$ & MS & $F$ & $\mathrm{p}$ & MS & $F$ & $\mathrm{p}$ \\
\hline \multicolumn{11}{|l|}{ Turf experiment } \\
\hline Transformation & & \multicolumn{3}{|c|}{ None } & \multicolumn{3}{|c|}{ Sqrt $(1+x)$} & & \multicolumn{2}{|c|}{$\operatorname{Ln}(0.1+x)$} \\
\hline Cochran's $C$ & & & 0.8371 & $<0.05$ & & 0.5345 & $>0.05$ & & 0.4354 & $>0.05$ \\
\hline Canopy & 1 & 28.2 & 5.17 & $<0.05$ & 0.123 & 0.47 & $>0.1$ & 16.3 & 7.88 & $<0.05$ \\
\hline Turf & 1 & 28.2 & 5.17 & $<0.05$ & 0.009 & 0.036 & $>0.1$ & 0.888 & 0.429 & $>0.1$ \\
\hline Canopy $\times$ Turf & 1 & 24.0 & 4.40 & $<0.05$ & 0.003 & 0.013 & $>0.1$ & 1.64 & 0.791 & $>0.1$ \\
\hline Residual & 20 & 5.45 & & & 0.261 & & & 2.07 & & \\
\hline \multicolumn{11}{|l|}{ Limpet experiment } \\
\hline Transformation & & \multicolumn{3}{|c|}{ None } & \multicolumn{3}{|c|}{ Sqrt $(1+x)$} & & \multicolumn{2}{|c|}{ None } \\
\hline Cochran's $C$ & & & 0.6801 & $<0.05$ & & 0.5129 & $>0.05$ & & 0.9931 & $<0.05$ \\
\hline Canopy & 1 & 45.4 & 14.1 & $<0.005$ & 5.98 & 2.74 & $>0.1$ & 216 & 1.03 & $>0.1$ \\
\hline Limpet & 1 & 45.4 & 14.1 & $<0.005$ & 70.6 & 32.4 & $<0.0001$ & 308 & 1.47 & $>0.1$ \\
\hline Canopy $\times$ Limpet & 1 & 35.0 & 10.9 & $<0.005$ & 5.98 & 2.74 & $>0.1$ & 216 & 1.03 & $>0.1$ \\
\hline Residual & 20 & 3.21 & & & 2.18 & & & 210 & & \\
\hline
\end{tabular}


Ulva spp. and silt. Sampling 1 yr later in 1999 showed that although Ascophyllum can recruit onto turfing algae, survival on this substrate was low (Fig. 1). Recruit densities were low in all treatments and no effect of either factor was found. Almost $7 \mathrm{yr}$ after initiation of the experiment, in May 2004, Ascophyllum juveniles were almost absent where the canopy was intact but showed an overall mean density of $35 \mathrm{~m}^{-2}$ where the canopy was removed, leading to a significant effect of the canopy (Table 1).

In the limpet experiment, recruitment was much higher than in the turf experiment. In November 1998, juveniles were only found in any number in plots where both Patella vulgata and the canopy were removed (Fig. 1), leading to an interaction between these factors (Table 1). After $1 \mathrm{yr}$, the number of juveniles was high in treatments where limpets were removed, irrespective of the presence of the canopy, and the effect of limpet removal was highly significant (Table 1). Thus, recruitment of juveniles (visible to the naked eye) to bare rock in the absence of limpets took longer where the canopy was intact, but reached at least the same level as in plots where the canopy was removed. After $5 \mathrm{yr}$, the overall density of Ascophyllum juveniles had declined, especially in the absence of the canopy. Beneath an intact canopy mean density was still relatively high (over $200 \mathrm{~m}^{-2}$ ) but showed high variability between replicates leading to no significant effects of any factor at this date. Throughout the experiment the number of juveniles on bare substrate in the presence of limpets was negligible, never reaching more than 3 juveniles $\mathrm{m}^{-2}$.
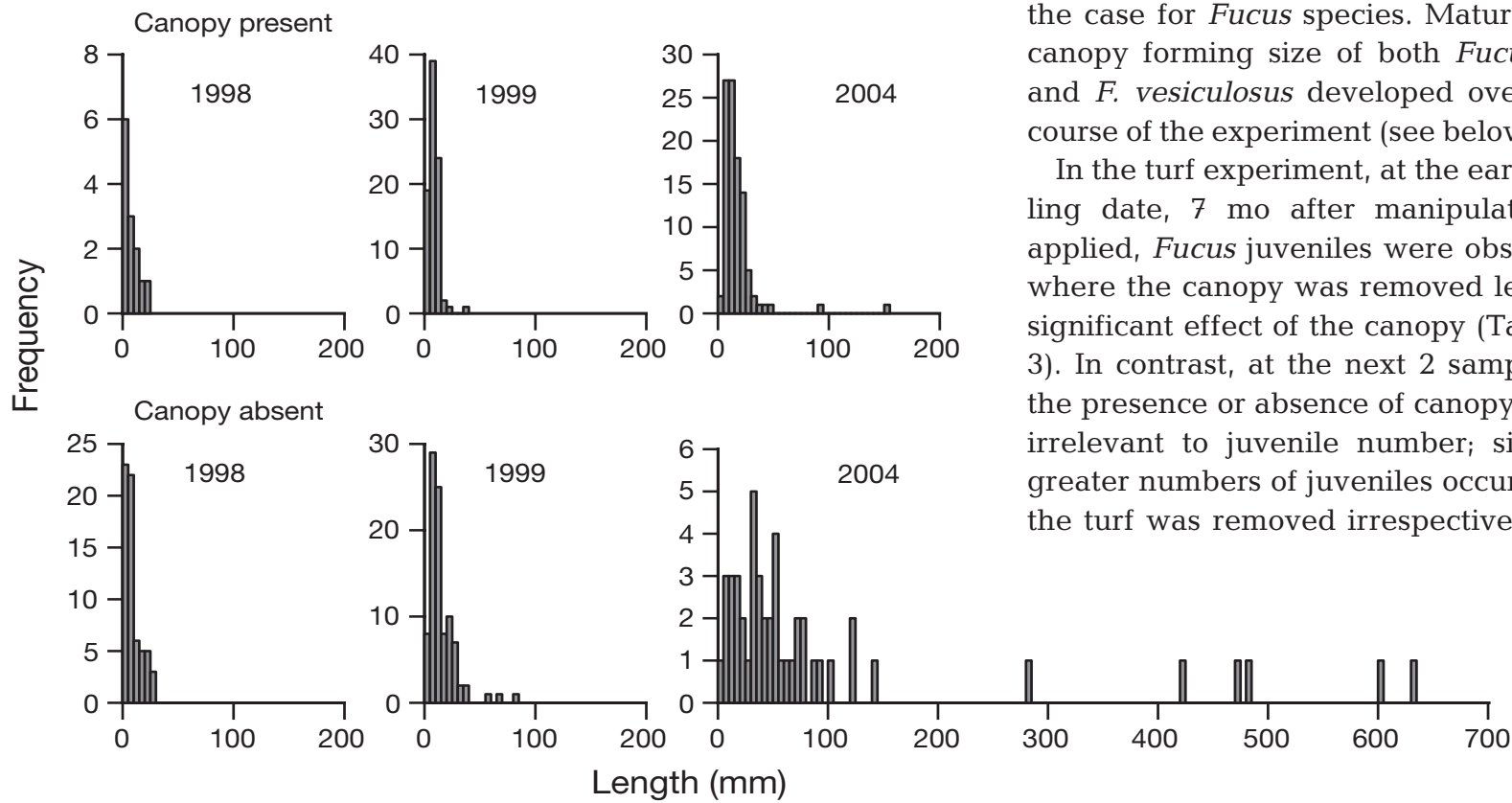

Fig. 2. Size distribution of recruiting Ascophyllum plants in the presence and absence of the overlying Asco-

\footnotetext{
phyllum canopy
}

\section{Ascophyllum size distribution}

Ascophyllum juveniles generally grew very slowly throughout the course of the experiment. The size distribution of plants differed depending on the presence or absence of the canopy but was not dependent on either limpet or turf presence. In the absence of the canopy, juveniles reached a modal size of $5 \mathrm{~mm}$ and maximum size of $20 \mathrm{~mm}$ after approximately 7 mo growth (assuming recruitment during spring 1998) (Fig. 2). After 1 yr, modal size was $10 \mathrm{~mm}$. Despite this low modal size a few individuals had reached a relatively large size, up to a maximum of $80 \mathrm{~mm}$. In 2004 the size distribution of Ascophyllum plants in the absence of the canopy had changed considerably. Modal size was still relatively low $(35 \mathrm{~mm})$ but a number of plants had grown to considerable size, up to a maximum of $630 \mathrm{~mm}$. In the presence of a canopy cover, juveniles grew more slowly and in 1999 the modal size (5 vs. $10 \mathrm{~mm}$ ) and maximum size (35 vs. $80 \mathrm{~mm}$ ) were lower than plots where the canopy was removed (Fig. 2). In 2004 modal size was $15 \mathrm{~mm}$ and only 2 plants had reached over $50 \mathrm{~mm}$ (maximum $=150 \mathrm{~mm}$ ).

\section{Fucus spp. recruitment}

Recruitment of Fucus species to manipulated plots began soon after the start of the experiment, with up to 2000 individuals $\mathrm{m}^{-2}$ in 1 plot by March 1998. Juvenile abundance peaked in November 1998. Whilst slow growth prevented development of mature Ascophyllum plants in experimental plots, this was not the case for Fucus species. Mature plants of canopy forming size of both Fucus serratus and $F$. vesiculosus developed over the time course of the experiment (see below).

In the turf experiment, at the earliest sampling date, 7 mo after manipulations were applied, Fucus juveniles were observed only where the canopy was removed leading to a significant effect of the canopy (Table 2, Fig. 3). In contrast, at the next 2 sampling dates the presence or absence of canopy cover was irrelevant to juvenile number; significantly greater numbers of juveniles occurred where the turf was removed irrespective of canopy 
cover (Table 2, Fig. 3). Owing to differences in growth rate in Fucus spp. beneath the canopy and in cleared plots, the percentage cover of Fucus spp. did not solely reflect numbers of individuals. This can be clearly seen at the sampling in November 1999 when the percentage cover of Fucus species was significantly higher where the canopy was removed, despite no effect of canopy on juvenile numbers (Table 2, Fig. 4).

In the limpet experiment, very few Fucus spp. individuals were found in March 1998. In November 1998 high numbers were found in plots where limpets were removed, irrespective of the presence of canopy cover, resulting in a significant effect of limpet removal (Table 2, Fig. 4). The same result was found $1 \mathrm{yr}$ later although numbers of individuals were far lower. The percentage cover of Fucus spp. was again affected by canopy removal, owing to enhanced growth rates in cleared plots. At the sampling in November 1999 there was a significant interaction between canopy and limpets, with the effect of limpet removal enhanced by clearance of the canopy (Table 2, Figs. 3 \& 4).

In 2004 a prominent canopy of Fucus serratus and $F$. vesiculosus had developed although the balance of the 2 species varied between experiments and treatments. In the turf experiment $F$. vesiculosus was only present where both canopy and turf were removed (Table 3, Fig. 5). In the limpet experiment $F$. serratus canopy cover was almost absent, but $F$. vesiculosus formed a high cover where the Ascophyllum canopy was removed (Table 3, Fig. 5). In contrast F. serratus was relatively abundant in both treatments where the canopy was removed, leading to a significant effect of canopy cover (Table 3, Fig. 5).

\section{Red turf forming algae}

Red turf forming algae showed changes in abundance (both positive and negative) throughout the experiment. In the limpet experiment, plots were initially chosen free from turf forming algae, and in general there was little development even when limpets were removed. In the turf experiment there was no change in the cover of turf in control plots over the 6 yr of observations. However, removal of the canopy led to turf degradation and a decline in cover from $100 \%$ to a mean $( \pm$ SE) of only $60 \%( \pm 17)$ in 1999 which was

Table 2. ANOVA of Fucus recruit number and percentage cover

\begin{tabular}{|c|c|c|c|c|c|c|c|c|c|c|}
\hline \multirow[t]{2}{*}{ Source } & \multirow[t]{2}{*}{$\mathrm{df}$} & \multicolumn{3}{|c|}{ March 1998} & \multicolumn{3}{|c|}{ November 1998} & \multicolumn{3}{|c|}{ November 1999} \\
\hline & & MS & $F$ & $\mathrm{p}$ & MS & F & $\mathrm{p}$ & MS & F & $\mathrm{p}$ \\
\hline \multicolumn{11}{|c|}{ Turf experiment, no. of Fucus recruits } \\
\hline Transformation & & & \multicolumn{2}{|c|}{$\operatorname{Ln}(0.1+x)$} & \multicolumn{3}{|c|}{ None } & & \multicolumn{2}{|c|}{ None } \\
\hline Cochran's $C$ & & & 0.4674 & $>0.05$ & & 0.6811 & $<0.05$ & & 0.5077 & $>0.05$ \\
\hline Canopy & 1 & 44.9 & 9.00 & $<0.01$ & 19200 & 0.400 & $>0.1$ & 3.38 & 0.001 & $>0.1$ \\
\hline Turf & 1 & 7.43 & 1.49 & $>0.1$ & 475000 & 9.90 & $<0.01$ & 58700 & 18.1 & $<0.001$ \\
\hline Canopy $\times$ Turf & 1 & 0.591 & 0.118 & $>0.1$ & 45000 & 0.937 & $>0.1$ & 1750 & 0.539 & $>0.1$ \\
\hline Residual & 20 & 4.99 & & & 960000 & & & 3250 & & \\
\hline \multicolumn{11}{|c|}{ Turf experiment, \% cover of Fucus } \\
\hline Transformation & & & \multirow{2}{*}{\multicolumn{2}{|c|}{$\begin{array}{c}\text { None } \\
0.9026<0.05\end{array}$}} & \multicolumn{3}{|c|}{$\operatorname{Ln}(0.1+x)$} & & \multicolumn{2}{|c|}{ None } \\
\hline Cochran's $C$ & & & & & & 0.3477 & $>0.05$ & & 0.4736 & $>0.05$ \\
\hline Canopy & 1 & 70.7 & 5.68 & $<0.05$ & 14.2 & 3.62 & $>0.05$ & 15300 & 13.5 & $<0.01$ \\
\hline Turf & 1 & 29.9 & 2.40 & $>0.1$ & 8.16 & 2.08 & $>0.1$ & 5830 & 5.13 & $<0.05$ \\
\hline Canopy $\times$ Turf & 1 & 26.5 & 2.12 & $>0.1$ & 3.40 & 0.870 & $>0.1$ & 542 & 0.476 & $>0.1$ \\
\hline Residual & 20 & 12.5 & & & 3.91 & & & 1140 & & \\
\hline \multicolumn{11}{|c|}{ Limpet experiment, no. of Fucus recruits } \\
\hline Transformation & & \multicolumn{3}{|c|}{ None } & \multicolumn{3}{|c|}{$\operatorname{Ln}(0.1+x)$} & & \multicolumn{2}{|c|}{ None } \\
\hline Cochran's $C$ & & & 0.9677 & $<0.05$ & & 0.4712 & $>0.05$ & & 0.5172 & $>0.05$ \\
\hline Canopy & 1 & 40.0 & 1.84 & $>0.1$ & 1.13 & 0.408 & $>0.1$ & 135 & 0.114 & $>0.1$ \\
\hline Limpet & 1 & 63.4 & 2.92 & $>0.1$ & 227 & 82.2 & $<0.0001$ & 16300 & 13.7 & $<0.01$ \\
\hline Canopy $\times$ Limpet & 1 & 40.0 & 1.84 & $>0.1$ & 6.27 & 2.27 & $>0.1$ & 165 & 0.139 & $>0.1$ \\
\hline Residual & 20 & 21.7 & & & 2.76 & & & 1190 & & \\
\hline \multicolumn{11}{|c|}{ Limpet experiment, \% cover of Fucus } \\
\hline Transformation & & \multicolumn{3}{|c|}{ None } & \multicolumn{3}{|c|}{$\operatorname{Ln}(0.1+x)$} & \multicolumn{3}{|c|}{$\operatorname{Arcsin}\left(\operatorname{Sqrt}\left(0.01^{*} x\right)\right)$} \\
\hline Cochran's $C$ & & & 0.9963 & $<0.05$ & & 0.5520 & $>0.05$ & & 0.5358 & $>0.05$ \\
\hline Canopy & 1 & 3.84 & 2.16 & $>0.1$ & 0.120 & 0.111 & $>0.1$ & 1.57 & 19.7 & $<0.001$ \\
\hline Limpet & 1 & 4.51 & 2.54 & $>0.1$ & 78.4 & 72.4 & $<0.0001$ & 4.93 & 57.9 & $<0.0001$ \\
\hline Canopy $\times$ Limpet & 1 & 3.84 & 2.16 & $>0.1$ & 0.343 & 0.316 & $>0.1$ & 0.778 & 9.82 & $<0.01$ \\
\hline Residual & 20 & 1.77 & & & 1.08 & & & 0.079 & & \\
\hline
\end{tabular}




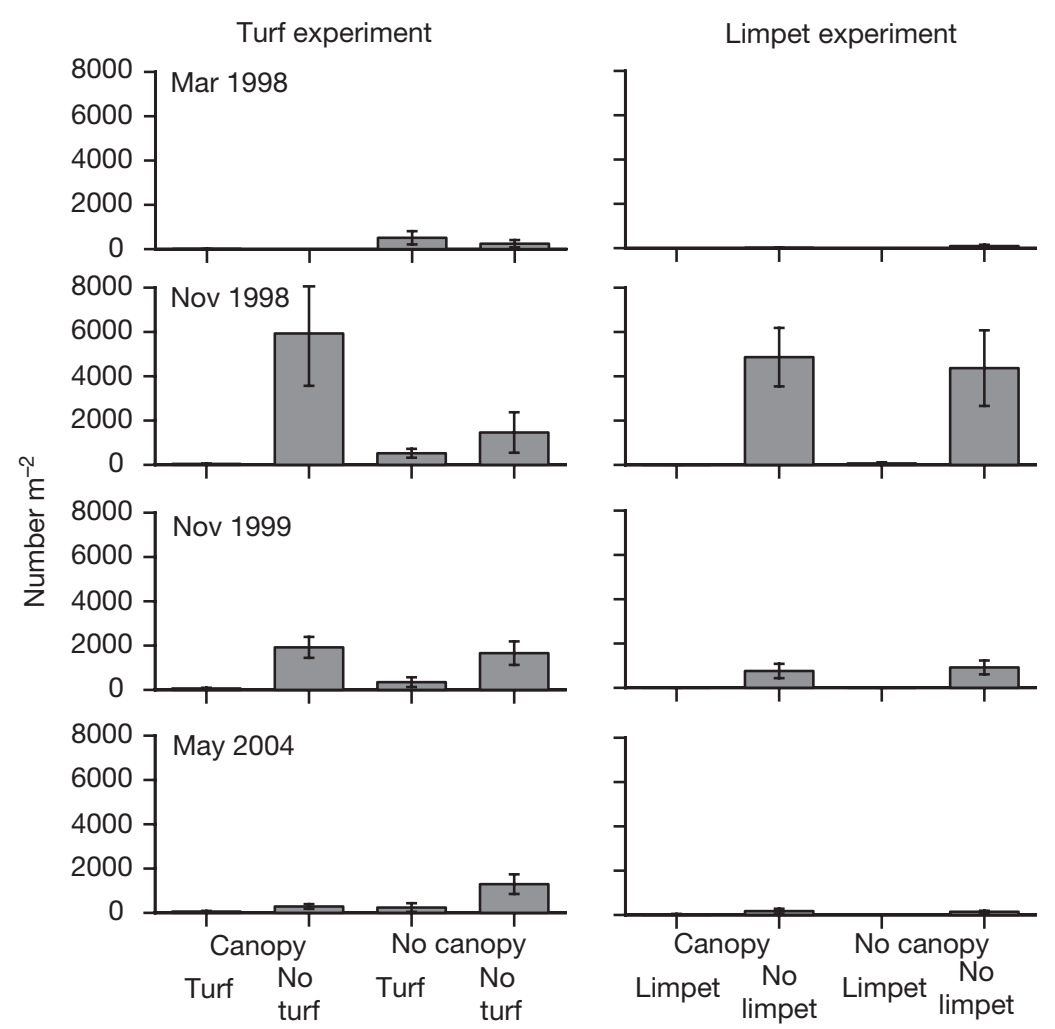

Fig. 3. Mean number of Fucus recruits $\mathrm{m}^{-2}$ at 4 sampling dates in the turf and limpet experiments $( \pm \mathrm{SE})$

maintained until 2004. At this point 2 out of the 6 replicates had completely changed character to ones dominated by bare rock, grazed upon by limpets. Recovery of turf following its removal was most rapid where the canopy was intact, leading to a significant effect of the canopy on turf recovery in 1999 (1-way ANOVA: $\operatorname{df}_{1,10} ; F=7.58$; $\mathrm{p}<$ $0.03)$. By 2004, turf had recovered to a mean $( \pm \mathrm{SE})$ of $72 \%( \pm 18)$ and $50 \%( \pm 17)$ cover in canopy intact and canopy absent plots respectively, although there was high variability between replicate plots.

\section{DISCUSSION}

Physical disturbance is one of the key processes regulating the community structure and dynamics of rocky shore assemblages. Disturbance on rocky shores, whether caused by direct wave action (e.g. Dayton \& Tegner 1984), wave born debris (e.g. Dayton 1971), ice (e.g. Mathieson et al. 1982, Åberg 1992), extended aerial exposure (e.g.
Schonbeck \& Norton 1978), or numerous other factors (see Sousa 2001 for review) often exerts its effects on community dynamics through the freeing up of limiting resources. Disturbance generally renews space but may also renew resources acquired by organisms while holding space (e.g. nutrients and light). In canopy dominated communities, for example, physical disturbance is frequently manifested as an extensive loss of macroalgal canopy cover (Dayton \& Tegner 1984, Dayton et al. 1992, Underwood 1998), which can allow access of understorey macroalgae to light (Kain 1975, Clarke et al. 2004). The disturbance regime in marine environments varies both in intensity and frequency. Most studies of its effects have focused on environments where disturbance is high. In contrast, we attempted to simulate natural levels of disturbance to the canopy and the understorey community in sheltered environments where the magnitude of disturbance is relatively low. Quantitative records of the regime of disturbance on rocky shores over long time scales are rare (see Sousa 2001), but observations suggest that on sheltered shores of NW Europe the intensity and
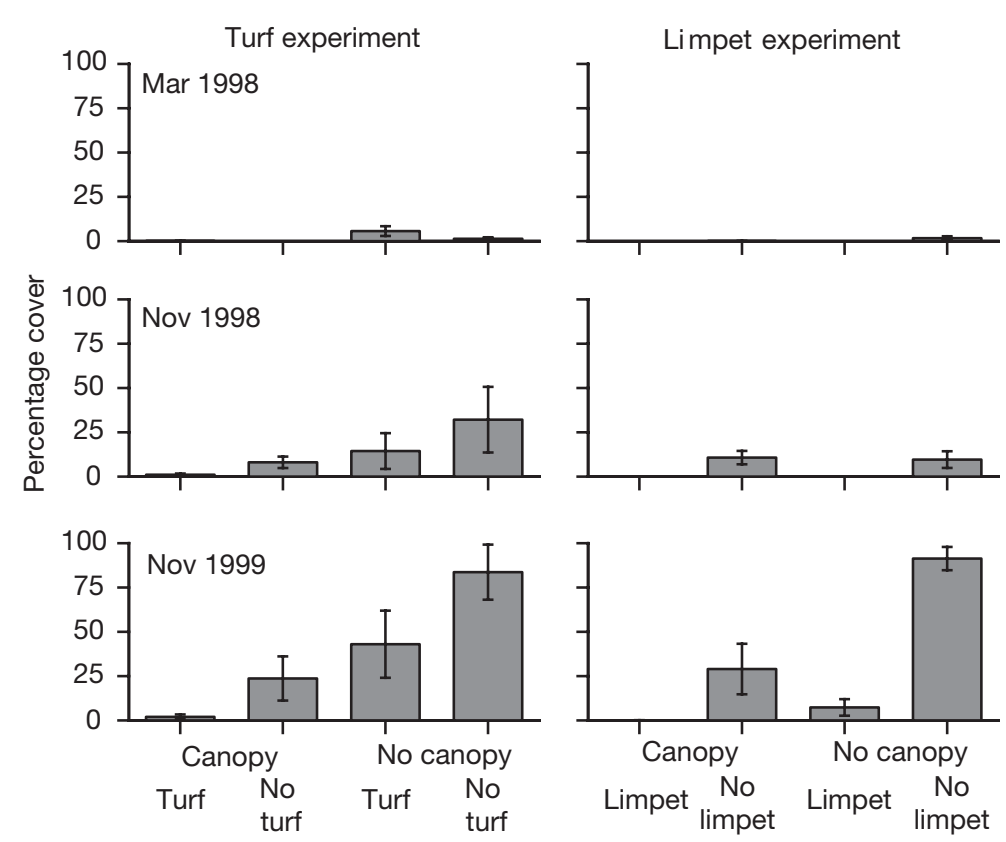

Fig. 4. Mean percentage cover of Fucus at 3 sampling dates in the turf and limpet experiments $( \pm \mathrm{SE})$ 
Table 3. ANOVA of percentage cover of the two species Fucus serratus and F. vesiculosus in May 2004

\begin{tabular}{|c|c|c|c|c|c|c|c|}
\hline \multirow[t]{2}{*}{ Source } & \multirow[t]{2}{*}{ df } & \multicolumn{3}{|c|}{ Fucus serratus } & \multicolumn{3}{|c|}{ Fucus vesiculosus } \\
\hline & & MS & $F$ & $\mathrm{p}$ & MS & $F$ & $\mathrm{p}$ \\
\hline \multicolumn{8}{|l|}{ Turf experiment } \\
\hline Transformation & & \multicolumn{3}{|c|}{ None } & \multicolumn{3}{|c|}{ None } \\
\hline Cochran's C & & & 0.4999 & $>0.05$ & & 0.9985 & $<0.05$ \\
\hline Canopy & 1 & 5800 & 8.65 & $<0.01$ & 1540 & 3.54 & $>0.05$ \\
\hline Limpet & 1 & 315 & 0.471 & $>0.1$ & 1410 & 3.26 & $>0.05$ \\
\hline Canopy $\times$ Limpet & 1 & 126 & 0.188 & $>0.1$ & 1410 & 3.26 & $>0.05$ \\
\hline Residual & 20 & 670 & & & 433 & & \\
\hline \multicolumn{8}{|l|}{ Limpet experiment } \\
\hline Transformation & & & Ln $(0.1$ & $+x)$ & Arcsin & (Sqrt $(0$. & $(01 \times x))$ \\
\hline Cochran's $C$ & & & 0.4302 & $>0.05$ & & 0.5399 & $>0.05$ \\
\hline Canopy & 1 & 8.96 & 2.61 & $>0.1$ & 1.82 & 27.8 & $<0.0001$ \\
\hline Limpet & 1 & 7.37 & 2.15 & $>0.1$ & 0.261 & 3.98 & $>0.05$ \\
\hline Canopy $\times$ Limpet & 1 & 7.37 & 2.15 & $>0.1$ & 0.261 & 3.98 & $>0.05$ \\
\hline Residual & 20 & 3.43 & & & 0.065 & & \\
\hline
\end{tabular}

red shores, not the overlying canopy. The results of the present study partially support this view for both Ascophyllum and Fucus species; provision of free ungrazed space in the understorey led to high density patches of recruits even where the canopy was not removed. By far the highest level of Ascophyllum recruitment occurred where limpets were removed but the canopy left in place, while the highest level of Fucus recruitment occurred where the turf was removed under an intact canopy. However, the situation is not entirely clear cut. On turf-dominated substrata, canopy removal was clearly required to enhance Ascophyllum recruitment. Numerous studies have demonstrated a negative effect of an adult canopy on juvenile recruitment

frequency of disturbance events are likely to be low (Jenkins et al. 2004).

Simulations of small-scale disturbance in a stable sheltered shore community resulted in significant changes to the understorey community, with enhanced levels of Ascophyllum and Fucus spp. recruitment and development of a Fucus vesiculosus and F. serratus canopy. Small, high density patches of Ascophyllum recruits (Åberg \& Pavia 1997), and patches of Fucus canopy (Jenkins et al. 1999a) occur naturally within the Ascophyllum zone. Our observations suggest that small-scale disturbance plays a role in the maintenance of such patterns. These observations are consistent with the intermediate disturbance hypothesis (Connell 1978) which predicts that moderate levels of disturbance to a highly dominant species, such as Ascophyllum nodosum, or the complex of species which form the red algal turf in the understorey, will promote local diversity by renewal of resources. Experimental evidence (e.g. Sousa 1979) and recent modelling studies (Dial \& Roughgarden 1998) provide support for this hypothesis. Our simulated disturbance provided ungrazed space in the understorey which promoted recruitment of both Fucus and Ascophyllum, and access to light which allowed development of adult Fucus canopy plants.

Jenkins et al. (1999a) speculated that preemption of space by turfing algae and intense grazing of unoccupied space by patellid limpets were the main factors limiting recruitment of Ascophyllum to shelte- (e.g. Burrows 1947, Hawkins \& Harkin 1985, Lubchenco 1986, Chapman 1989, 1990, Brawley \& Johnson 1991, Benedetti-Cecchi \& Cinelli 1992). Sweeping by algal fronds has been invoked as a means by which this inhibition occurs (Black 1974, Brawley \& Johnson 1991), and indeed a direct negative effect of sweeping has been proven experimentally (Johnson 1993). However, the negative effect of an adult canopy on recruitment is not consistent across species. For example, Brawley \& Johnson (1991) showed an adult canopy protects recruits of Pelvetia fastigiata from desiccation stress whilst Jenkins et al. (1999b) showed
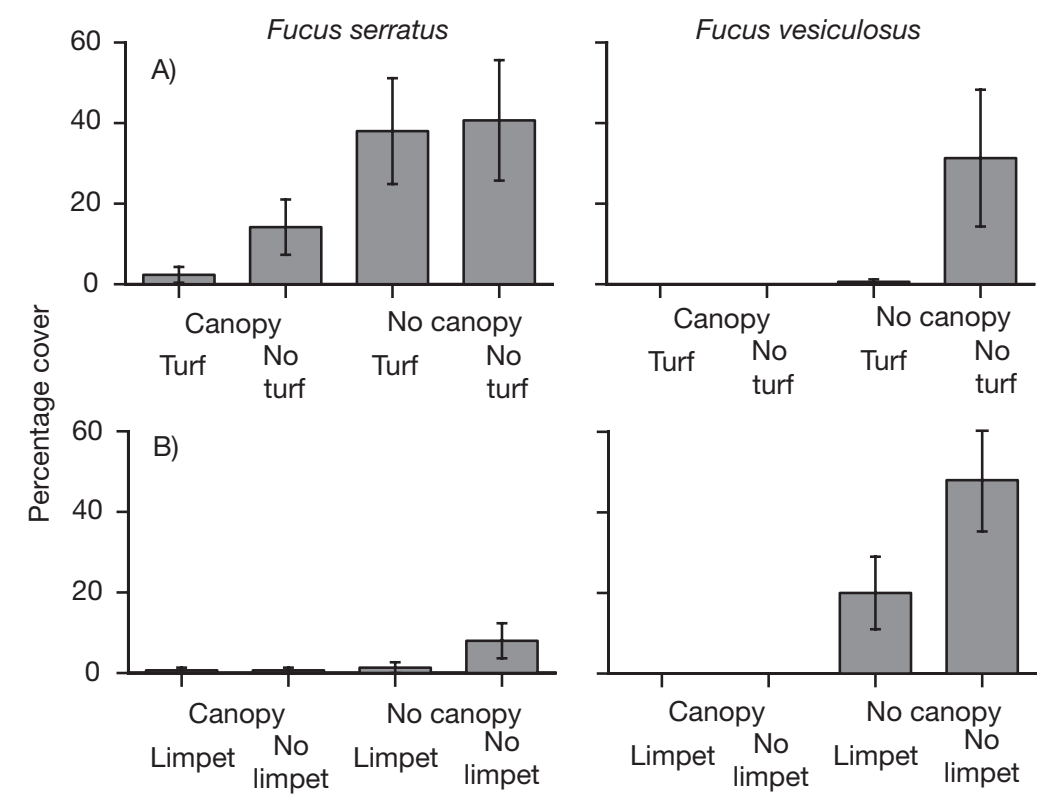

Fig. 5. Mean percentage cover of Fucus serratus and F. vesiculosus in the turf and limpet experiments in May $2004( \pm$ SE) 
that recruitment of Fucus serratus was dependent on protection from grazing rather than from sweeping of the adult canopy.

Observations of juvenile growth showed that while the overlying canopy may in some cases have little effect on recruitment, it has strong inhibitory effects on growth of both Ascophyllum and Fucus recruits. The modal size classes of Ascophyllum plants in experimental plots without canopy after 6 yr were more than double those with an intact canopy and the maximum size was over 4 times as great. Despite this, individuals were generally too scarce and too slow-growing to observe any effect of canopy removal on the overall cover of new plants. Enhanced growth of Fucus species following canopy removal led to an additive effect of the canopy and the other manipulated factor on the percentage cover of Fucus. In 1999 the cover of Fucus species was greatest in both the limpet experiment and turf experiment where both factors were manipulated. Thus although loss of the canopy and either grazers (limpets) or algal competitors for space (the turf) does not necessarily lead to the highest level of recruitment, it does lead to the greatest community level consequences i.e. the greatest cover of a Fucus canopy. Competing fucoids will exploit areas where grazing pressure is lowered or the turf is lost, but the growth of these plants is dependent on loss of canopy. Over $6 \mathrm{yr}$ after canopy removal this resulted in a cover of mainly $F$. serratus canopy on turf dominated substratum (independent of the turf treatment), and a cover of mainly $F$. vesiculosus on limpet grazed substratum provided that the grazing pressure was lowered. The reasons for the difference in species composition between substrata are not known.

The recent work in the Gulf of Maine (Petraitis \& Dudgeon 1999, Petraitis \& Latham 1999, Dudgeon \& Petraitis 2001, Bertness et al. 2002) in Ascophyllum dominated communities has taken a similar approach to ours in examining the community level consequences of realistic levels of disturbance. However, in Maine the natural levels of disturbance from ice scouring are high and debate has focused on whether such disturbance can cause a switch between alternate stable states of Ascophyllum or mussel domination. On sheltered shores in NW Europe, the intensity and frequency of disturbance is low. However, results show that on a much smaller scale, disturbance in Ascophyllum communities can cause very long lasting changes to both canopy and understorey community structure. Jenkins et al. (2004) reported very little recovery of the Ascophyllum canopy 12 yr after its removal, although they still speculated that Ascophyllum would eventually return, i.e. the community was in a process of gradual successional change involving a long lived slow growing species. Canopy removal also resulted in degradation of the understorey turf, an expansion of grazer controlled 'bare substratum' and an increase in the limpet population of experimental plots. Thus $12 \mathrm{yr}$ on plots were dominated by 'bare substratum' and limpets. This result was also apparent in the present study based on a much smaller disturbance; removal of the canopy led to turf loss and 2 out of 6 plots changed from turf to limpet domination.

In summary we showed that small-scale disturbance in a stable community provide 'windows' of opportunity to facilitate the co-existence of species, namely Fucus serratus and F. vesiculosus within stands of a superior competitor, Ascophyllum nodosum (see also Cervin et al. 2004). Disturbance resulted in patches of mature Fucus species within the Ascophyllum 'zone' and patches of high density Ascophyllum recruits with the potential of forming a canopy over a long period of time ( $>10$ yr). The mechanism by which these changes occurred was predominantly through provision of free ungrazed space in the understorey to promote recruitment, but loss of the Ascophyllum canopy was required to allow recruits of Fucus to develop into a mature canopy. Our results confirm that loss of Ascophyllum canopy on a small scale can lead to long term changes in canopy and understorey structure.

Acknowledgements. We thank the staff at Port Erin Marine Laboratory, Isle of Man for their hospitality, and S. Kay, E. LaCroix and S. Wilson for their help with fieldwork. This study was funded by a studentship to G.C. from the Faculty of Science, Göteborg University, as part of a $\mathrm{PhD}$ thesis in Marine Botany at the Department of Marine Ecology (Göteborg University). Additional funding for long-term experimental work and write up was provided by the Mast III project Eurorock MAS3-CT95-0012 and an MBA fellowship to S.R.J. The experiments performed in the present study comply with current Isle of Man and Swedish laws. The helpful comments of P. Dayton and 3 anonymous referees substantially improved the manuscript.

\section{LITERATURE CITED}

Åberg P (1992) A demographic study of two populations of the seaweed Ascophyllum nodosum. Ecology 73:1473-1487

Åberg P, Pavia H (1997) Temporal and multiple scale spatial variation in juvenile and adult abundance of the brown alga Ascophyllum nodosum. Mar Ecol Prog Ser 158:111-119

Baardseth E (1970) Synopsis of biological data on Knobbed wrack Ascophyllum nodosum (Linnaeus) Le Jolis. FAO Fish Synop 38

Benedetti-Cecchi L, Cinelli F (1992) Effects of canopy cover, herbivores and substratum type on patterns of Cystoseira spp. settlement and recruitment in littoral rockpools. Mar Ecol Prog Ser 90:183-191

Bertness MD, Trussell GC, Ewanchuk PJ, Silliman BR (2002) Do alternate stable community states exist in the Gulf of Maine rocky intertidal zone? Ecology 83:3434-3448

Black R (1974) Some biological interactions affecting intertidal populations of the kelp Egregia laevigata. Mar Biol 28: 189-198 
Brawley SH, Johnson LE (1991) Survival of fucoid embryos in the intertidal zone depends upon developmental stage and microhabitat. J Phycol 27:179-186

Burrows EM (1947) A biological investigation of the behaviour of Ascophyllum nodosum over a period of years and an inquiry into its relations with other components of the algal flora. $\mathrm{PhD}$ thesis, London University

Cervin G, Lindegarth M, Viejo RM, Åberg P (2004) Effects of small-scale disturbances of canopy and grazing on intertidal assemblages on the Swedish west coast. J Exp Mar Biol Ecol 302:35-49

Chapman ARO (1989) Abundance of Fucus spiralis and ephemeral seaweeds in a high eulittoral zone: effects of grazers, canopy and substratum type. Mar Biol 102:565-572

Chapman ARO (1990) Effects of grazing, canopy cover and substratum type on the abundances of common species of seaweeds inhabiting littoral fringe tide pools. Bot Mar 33: 319-326

Clark RP, Edwards MS, Foster MS (2004) Effects of shade from multiple kelp canopies on an understory algal assemblage. Mar Ecol Prog Ser 267:107-119

Coleman RA, Goss-Custard JD, Le V. dit Durell SEA, Hawkins SJ (1999) Limpet Patella spp. consumption by oystercatchers Haematopus ostralegus: a preference for solitary prey items. Mar Ecol Prog Ser 183:253-261

Connell J (1978) Diversity in tropical rainforests and coral reefs. Science 199:1302-1310

David HM (1943) Studies in the autecology of Ascophyllum nodosum Le Jol. J Ecol 31:178-198

Dayton PK (1971) Competition, disturbance, and community organization: the provision and subsequent utilization of space in a rocky intertidal community. Ecol Monogr 41:351-389

Dayton PK, Tegner MJ (1984) Catastrophic storms, El Niño, and patch stability in a California kelp community. Science 224: 283-285

Dayton PK, Tegner MJ, Parnell PE, Edwards PB (1992) Temporal and spatial patterns of disturbance and recovery in a kelp forest community. Ecol Monogr 62:421-445

Dial R, Roughgarden J (1998) Theory of marine communities: the intermediate disturbance hypothesis. Ecology 79: $1412-1424$

Dudgeon S, Petraitis PS (2001) Scale-dependent recruitment and divergence of intertidal communities. Ecology 82: 991-1006

Hawkins SJ (1983) Interactions of Patella and macroalgae with settling Semibalanus balanoides (L.). J Exp Mar Biol Ecol 71: $55-52$

Hawkins SJ, Harkin E (1985) Preliminary canopy removal experiments in algal dominated communities low on the shore and in the shallow subtidal on the Isle of Man. Bot Mar 28: $223-230$

Jenkins SR, Hawkins SJ, Norton TA (1999a) Direct and indirect effects of a macroalgal canopy and limpet grazing in structuring a sheltered inter-tidal community. Mar Ecol Prog Ser 188:81-92

Jenkins SR, Hawkins SJ, Norton TA (1999b) Interaction between a fucoid canopy and limpet grazing in structuring a low shore intertidal community. J Exp Mar Biol Ecol 233: 41-63

Jenkins SR, Norton TA, Hawkins SJ (2004) Long term effects of Ascophyllum nodosum canopy removal on mid shore community structure. J Mar Biol Assoc UK 84:327-329

Johnson S (1993) Surface microtopography and the fate of seaweed propagules. PhD thesis, University of Liverpool

Kain J (1975) Algal recolonization of some cleared subtidal areas. J Ecol 63:739-765

Keser M, Larson BR (1984) Colonization and growth of Ascophyllum nodosum (Phaeophyta) in Maine. J Phycol 20:83-87
Keser M, Vadas RL, Larson BR (1981) Regrowth of Ascophyllum nodosum and Fucus vesiculosus under various harvesting regimes in Maine, USA. Bot Mar 24:29-38

Knight M, Parke M (1950) A biological study of Fucus vesiculosus L. and F. serratus L. J Mar Biol Assoc UK 29:439-514

Lazo L, Markham JH, Chapman ARO (1994) Herbivory and harvesting: effects on sexual recruitment and vegetative modules of Ascophyllum nodosum. Ophelia 40:95-113

Lewis JR (1964) The ecology of rocky shores. The English Universities Press, London

Lubchenco J (1986) Relative importance of competition and predation: early colonization by seaweeds in New England. In: Diamond J, Case TJ (eds) Community ecology. Harper \& Row, New York, p 537-555

Mathieson AC, Penniman CA, Busse PK, Tveter-Gallagher E (1982) Effects of ice on Ascophyllum nodosum within the Great Bay estuary system of New Hampshire-Maine. J Phycol 18:331-336

McCook LJ, Chapman ARO (1991) Community succession following massive ice-scour on an exposed rocky shore: effects of Fucus canopy algae and of mussels during late succession. J Exp Mar Biol Ecol 154:137-169

Oltmanns F (1889) Beiträge zur Kenntnis der Fucaceen. Bibliotheca Botanica 14:1-94

Petraitis PS, Dudgeon SR (1999) Experimental evidence for the origin of alternative communities on rocky intertidal shores. Oikos 84:239-245

Petraitis PS, Latham RE (1999) The importance of scale in testing the origins of alternative community states. Ecology 80: $429-442$

Printz H (1956) Recuperation and recolonisation in Ascophyllum. In: Braarud T, Sørensen NA (eds) Second International Symposium. Pergamon Press, Trondheim, p 194-197

Reed DC, Foster MS (1984) The effects of canopy shading on algal recruitment and growth in a giant kelp forest. Ecology 65:937-948

Schiel DR, Taylor DI (1999) Effects of trampling on a rocky intertidal algal assemblage in southern New Zealand. J Exp Mar Biol Ecol 235:213-235

Schonbeck M, Norton TA (1978) Factors controlling upper limits of fucoid algae on shore. J Exp Mar Biol Ecol 31:303-313

Sousa WP (1979) Experimental investigations of disturbance and ecological succession in a rocky intertidal algal community. Ecol Monogr 49:227-254

Sousa WP (2001) Natural disturbance and the dynamics of marine benthic communities. In: Bertness M, Gaines S, Hay M (eds) Marine community ecology. Sinauer Associates, Sunderland, MA, p 85-130

Sundene O (1973) Growth and reproduction in Ascophyllum nodosum (Phaeophyceae). Norw J Bot 20:249-255

Thompson RC, Jenkins SR, Bussell JA (2000) A method for recording predator-prey encounters between crabs and limpets using wax replicas. J Mar Biol Assoc UK 80:633-638

Underwood AJ (1998) Grazing and disturbance: an experimental analysis of patchiness in recovery from a severe storm by the intertidal alga Hormosira banksii on rocky shores in New South Wales. J Exp Mar Biol Ecol 231:291-306

Vadas RL, Johnson S, Norton TA (1992) Recruitment and mortality of early post-settlement stages of benthic algae. $\mathrm{Br}$ Phycol J 27:331-351

Velimirov B, Griffiths CL (1979) Wave-induced kelp movement and its importance for community structure. Bot Mar 22: 169-172

Viejo RM, Åberg P (2003) Temporal and spatial variation in the density of mobile epifauna and grazing damage on the seaweed Ascophyllum nodosum. Mar Biol 142:1229-1241

Winer BJ, Brown DR, Michels KM (1991) Statistical principles in experimental design. McGraw-Hill, New York 